This item was submitted to Loughborough's Research Repository by the author.

Items in Figshare are protected by copyright, with all rights reserved, unless otherwise indicated.

\title{
Crime, technology and the future
}

PLEASE CITE THE PUBLISHED VERSION

PUBLISHER

(C) Perpituity Press

LICENCE

CC BY-NC-ND 4.0

REPOSITORY RECORD

Davis, Richard, and Ken Pease. 2019. "Crime, Technology and the Future". figshare. https://hdl.handle.net/2134/918. 


\title{
Crime, Technology and the Future
}

\author{
Richard Davis and Ken Pease
}

The findings which are currently emerging from the Foresight Crime Prevention Panel were published in March 2000. The Panel and its four task forces have been looking, up to 20 years ahead, at how new technology might impact upon crime and crime prevention. As part of this it has also sought to consider the social changes which might occur, and how these might influence both crime and the use of technology.

Key words: Crime prevention; Foresight

\section{Introduction}

The Foresight Crime Prevention Panel is funded from the government's Crime Reduction Programme (CRP). Foresight is based within the Office of Science and Technology, which is itself based within the Department for Trade and Industry. It works through bringing together business, academia, government and others to identify new technology and to consider its impact, taking a view up to 20 years into the future.

This Panel is one of thirteen within the second round of the Foresight programme, which began in April 1999. It is looking at crime widely, with detection included in its remit because it believes this contributes to prevention. Purely social approaches to crime prevention are outside that remit.

The Panel:

- $\quad$ is exploring the crime potential of new technologies, and identifying opportunities for using advances in technology to reduce crime;

- $\quad$ is advocating the 'designing out' of crime in products and environments so that crime potential is reduced at the earliest possible stage;

- $\quad$ is ensuring that other Foresight panels consider crime and crime prevention when taking their work forward;

- $\quad$ is engaging a wide audience of stakeholders at all stages of its work; and

- $\quad$ will make recommendations for action when it reports in November 2000.

The Panel is chaired by Lord Sharman of Redlynch; its other members are drawn from business, academia, government, and the voluntary and public sectors. The four task forces are looking 


\section{Security Journal}

respectively at the following: biology and gene technologies; chemicals and materials; IT, electronics and communications; and crime in future society. In total some 60 people have worked on this project since it started. The emerging results are a summary of the discussions these groups have had. The Panel is not seeking to be definitive nor prescriptive at this stage, but it is seeking a genuine debate about crime, the future, technology and society. In all of these, it is seeking an answer to the questions of what they will look like and, perhaps more importantly, what we would want them to look like.

While looking 20 years ahead, Foreisght is not just about blue-skies technology and horizon gazing. So, although those developing new technology are being asked to consider its implications, both positive and negative, the Panel is also seeking to bring together a) those working in science and technology within academia and business with b) law enforcement and crime prevention. As anyone who has worked in the field knows, there is much which could already be done to reduce crime using technology — from tagging goods with chips, coatings or fibres to greater use of new technology in allowing communities to communicate and protect themselves. The Panel is making these links wherever possible.

The report in November 2000 will be making recommendations for action in a number of areas: for the government, in terms of any legislative issues the Panel sees arising; for law enforcement agencies, about how they might need to adapt to the new challenges; for areas of research and development, where funding could usefully be targeted. On this last point, Foresight is primarily concerned with technology, and its recommendations for funding will largely focus upon scientific and technological research. The Panel is intent on assisting good ideas to achieve access to funding, whether it comes from the DTI, the Home Office or elsewhere. We are, however, currently pulling together a list of possible, predominantly socioeconomic research projects which we would wish to see completed before November 2000

\section{What will happen to crime in the future?}

Looking at the future, certain givens have to be accepted in relating the possible future to the tangible present. The Panel has therefore accepted that crime is, and will always be, either acquisitive (property theft, fraud, etc) or expressive (violence, vandalism, disorder, etc). In addition, it recognises the different types of criminal, ranging from the opportunistic, through the career criminal, to organised crime and those who spread terror.

\section{What social characteristics will affect crime?}

Drawing on the Foresight document Britain: Towards 2010, and using the four Foresight Environmental Future scenarios (which have the axes of globalisation-regionalisation and consumerism-community), we believe the following characteristics of society will influence crime.

\section{Individuality and independence}

Britain: Towards 2010 expects that 'traditional family forms will no longer be the 'foundation' of society. More of the population will live alone in single-person households ... [there will be] more self-centred, self-indulgent and hedonistic psychologies'. Crime will become more likely, as the social pressures which currently limit anti-social behaviour become eroded. Traditional communities may be replaced by groups which come together around shared beliefs/ interests rather than because of geographical location. Such groups may reinforce rather than 
challenge anti-social views. Moreover, movement them between will be easier, and the level of commitment to communities may be reduced as a result.

Use of information communication technologies (ICTs)

The dominance of, and changes brought about by, these technologies will have profound effects on crime, and in particular on its potential for increased speed and scale. Crimes such as electronic theft and fraud will occur more quickly, reducing the likelihood of being caught in the act. Information about how to compromise a system will be available more quickly and to more people. The education and ability of criminals to use new technology will also have a major impact on the sort of crime we will see.

As well as increases in speed and scale, ICTs offer greater complexity. This will be significant in terms of setting standards, trans-border crime, police jurisdictions, judicial systems and legislation. In particular, complexity will offer increasing difficulties in explaining evidential trails to a jury. This in turn raises the whole question of the accessibility of digital evidence in court.

There are increasing opportunities for people to be isolated in public space. Business, interpersonal and entertainment activities have moved from the social and static to the personal and mobile. People have greater choice as to who they 'meet' and how. Physical society may, therefore, become a more hostile place, through which people travel rather than in which they expect to interact. In a dehumanised environment, people may become less 'real' to one another, leading to more extreme reactions and interactions.

In cyberspace, we can expect this to be further magnified. The relationship between the offender and victim, in particular, may change, as neither is aware of the other as a person. The lack of such awareness may see on-line offenders committing more extreme crimes. Equally, if victims have no contact with the offender, their attitudes to punishment may change. Whether this will see a reduction in demands for punishment (as a result of the lack of physical intrusion/ experience of the crime) or an increase in those for harsher penalties (because of the victim's detachment from the offender) is not clear.

\section{Globalisation}

This is most likely in commerce, communication and crime rather than in governance. Consumerism, rather than communalism, is the social philosophy expected to be dominant. Already crimes on the Internet, smuggling and drug dealing show the power of global crime and the difficulties this poses for local-level law enforcement. A greater global culture might provoke a rise in local/regional identities as a response. Within this, we should be alive to the potential for social exclusion of those not seen as 'belonging' in the community. We might also see more ad-hoc virtual organisations developing, sharing information without formal links. The traditional tool of targeting known criminal organisations may not work so well in this environment. The ability and tendency for those on the Internet to broadcast information when available could conceivably harm criminal endeavours as well as those of law enforcement and crime prevention.

\section{What will have value?}

Acquisitive crime always follows what has value, either to the criminal directly or in the wider market for stolen goods. In a digital future, however, the value may well reside in 'electronic property'. The Panel has considered the future of both physical and electronic property theft. 


\section{Security Journal}

Property theft can be expected to continue for a large part of this period. Current targets for the opportunistic criminal, such as cash, electrical entertainment goods, bank cards and cameras may, however, become less attractive if their ability to be turned into profit is tied to the individual (through interconnected components housed in clothing or smart cards). Alternatively, the opportunities for tagging goods, through chips, coatings, fibres and other smart technology could significantly reduce the stolen goods market.

We have therefore put great emphasis on the ways technology might do this, including: electronic chips within a product; a chemical or biological coating or implant; materials which are themselves unique or recognisable at a fundamental level; linked components which establish an identity; or any combination of these. Similarly, by linking a system's operation to a location - possibly through global positioning technology, or by coding the equipment to work only from a particular power supply - the product can be rendered useless to anyone other than the owner.

We have identified three new or growing areas of value. We believe these will become new targets for criminals, especially if physical property is made a more difficult target. There is no indication as yet about which forms of these will be most vulnerable.

\section{Electronic services}

More and more electronic entertainment equipment is delivered as a service-usually in the form of a signal. Televisions, mobile phones and computers are all means of delivering the service - and the electronic equipment itself is increasingly becoming nothing more than the access point to the service. As such, there is every likelihood that the hardware will increasingly be sold cheaply or given away free, as a way of attracting customers to the service.

This will not be limited to current signal-based entertainment. Already music downloaded from the Internet and 'video on demand' are showing there is little which cannot be provided as a service rather than in 'hard' form. If this happens, then the hardware so popular with thieves at present will become unattractive, because the real value will reside in the service. This is now the subject of a research project with Leeds University.

\section{Knowledge and information}

Knowledge and information are often spoken of as the key to the future. With the prevalence of the Internet and whatever comes after it, we can expect knowledge to be more widely available than ever. Already we are seeing crimes of 'knowledge theft' and this can only grow in such a future, especially as the knowledge economy grows. Intellectual property offences include: primary and secondary copyright infringement; copying or imitating of trademarks; and breach of confidence. This is an area where consistent international law seems the solution. For adherence to the law, however, public education will be necessary if people are to treat the infringement of these rights as a crime.

\section{Identity}

Ways of proving identity in the future will increase, as will the number of occasions and areas in which such proof is necessary - often for our own protection. The means will range from a secure Internet identity, through biometric smart cards which only work in conjunction with a particular body, to a range of odour detectors, DNA analysis and computer-based recognition systems for allowing access to premises, goods, facilities and services. One's identity will have value, and therefore will become a target. Identity crimes may be facilitated either by counterfeit identifiers or by the misuse of legitimate identifiers. 


\section{How will crime change?}

Given all the above, we would expect:

- $\quad$ violence to rise;

- $\quad$ fraud/extortion to increase;

- $\quad$ theft to become more virtual.

Violence, disorder and destruction may result from a growing social exclusion, brought about by technological exclusion coupled with an increasingly individualised society. Also, these offences may rise in number, as products become harder to steal through advances in tagging, coating, tracking and immobilising. We should not, therefore, lose sight of what is often the weakest link in any defence: the person. People may be targeted because they can provide legitimate access to whatever is protected (whether premises, a computer system or goods). Again, if social exclusion cannot find an outlet in robbery, it may move to disorder and violence.

Similarly, as crime detection improves through advances in forensic science (including analysis of DNA samples) the question arises of how criminals might cover their tracks. Some may find 'high-tech' ways of leaving false trails at scenes. More worrying would be the more extreme response of destroying as effectively as possible the crime scene itself (arson or explosives being the most obvious means).

That crime is being translated to the Internet is already old news. Fraud, which has always been under-reported, is ideally suited to the Internet. Fraud can be used simply for direct financial gain, or to obtain information which might allow this (eg, 'front' websites which might record credit-card details for direct misuse or seek personal and financial information which could be used to create a false identity). Again, the question of obtaining legitimate access to systems might mean that blackmail increases, as another way of coercing those with such access to aid the criminal.

It is likely that even if business use is secure, general use will not be, creating safe and unsafe areas. Users will need to know from which sort of domain a message has originated when considering how to respond. Public education, particularly about the risks, is essential if fear of crime is not to prevent the uptake and acceptance of new technology.

While the Internet is not yet central to national economic and social life, it is expected to be part of the essential infrastructure within 10 years - it could therefore become a target for terrorism and crime.

If society moves more and more towards being service-based, those who provide such services (both electronic and real) will become the target of more crime. Such crime may be seen as 'victimless', as it will not target individuals; it may require a greater complicity from society in general than at present, and this may be justified by some as a reaction to the power of service providers.

\section{So what?}

The debate which we wish to start will raise questions for those around and about the law enforcement area. What are the implications for civil liberties? Will we see this discussion move from whether information is kept on individuals to people demanding that information 


\section{Security Journal}

be held for their own protection (for example, using their identity for secure access to computers, premises or services)? If so, will the debate focus on how the information is stored, and on who has access?

For law enforcement agencies, questions arise about what these bodies should do in response to changing crime. Two immediate questions arise: what sort of skills and people law enforcement will need (more bobbies on the beat or more analysts on the Net); and whether the highly localised system of 43 police forces in England and Wales is suitable for tackling increasingly global crime.

There are also questions about the sort of technology which people will find acceptable. Are there some technologies which will be so convenient that, despite other concerns, they will be widely taken up? What 'feel-safe' elements will technology need to attract customers and reduce fears of intrusion?

Copies of the consultation paper, "Just Around the Corner" are available from Foresight either by faxing a request to 01712156715 or on-line from the Crime Prevention Panel's part of the Foresight Knowledge Pool: www.foresight.gov.uk. 